\title{
How urban was fifth-century BC Bourges?
}

\section{Gilbert Kaenel*}

Laurence Augier, Olivier Buchsenschutz \& Ian RALSTON (ed.). Un complexe princier de l'àge du Fer: l'habitat du promontoire de Bourges (Cher) $\left(V I^{e}-I V^{e}\right.$ s. av. J.-C.). 200 pages, $160 \mathrm{~b} \& \mathrm{w} \&$ colour illustrations. 2007. Bourges: Bourges Plus, Service d'archéologie préventive; 978-2-913272-17-0 paperback.

Pierre-Yves Milcent (ed.). Bourges Avaricum: un centre proto-urbain celtique $d u V^{e}$ siècle av. J.-C. Les fouilles du quartier Saint-Martin-desChamps et les découvertes des Etablissements militaires. Volume 1: 344 pages, numerous illustrations \& tables. Volume 2: 176 pages of b\&w \& colour illustrations \& tables. 2008. Bourges: Ville de Bourges, Service d'archéologie municipal; 978-29514097-7-4 paperback $€ 40$ (both volumes).

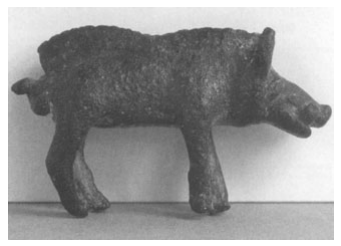

These two simultaneously published works (the second in two volumes) mark an important stage in French Iron Age research, for the end

of the early (or first) Iron Age and beginning of the later (or second) Iron Age, i.e. the Hallstatt D and La Tène A phases. The discoveries made since the nineteenth century in Bourges in central France, but especially those resulting from interventions (in particular by Olivier Ruffier and Jacques Troadec) carried out as a prerequisite of urban and suburban redevelopment since the 1980s, have radically altered our understanding of the sixth and fifth centuries BC. This period of European protohistory is proving exceptionally rich in questions, oft vigorously debated amongst researchers discussing sometimes divergent models and concepts surrounding what is known as the 'western Hallstatt domain' (Westhallstattkreis), its famous 'princely centres' (Fürstensitze) and richly furnished barrow burials, such as those found in the neighbourhood of Bourges. Excavations are indeed continuing on the northern outskirts of the town providing fresh fuel for renewed debate.

Let us state at the outset that the two works complement each other, even if their objectives and interpretations, clearly revealed by their respective titles, differ. Both contribute to very topical research questions, pursued notably within the framework of a huge project undertaken in southern Germany by the Deutsche Forschungsgemeinschaft (under completion) or by the work carried out at the Mont Lassois, Vix and surroundings in Burgundy.

The authors of the first volume - basing themselves on the data derived from the settlement which occupied the limestone promontory at the centre of a fertile loop in the river Loire under the present city of Bourges - choose to refer to a 'princely complex', thus including peripheral sectors and enlarging the more narrowly defined concept of a 'princely seat' current in the 1970s and 1980s, whereas the authors of the second volume speak of a 'proto-urban centre', which refers to settlement remains found $2-3 \mathrm{~km}$ north-west of the central promontory between the rivers Yèvre and Auron. Thus we are at the heart of current issues; for our part, we would prefer to talk of centralisation or concentration of settlement and activities, and of 'urbanisation processes' in the plural form (Urbanisierungsprozesse) following the terminology of the German project. We are indeed somewhat reticent in accepting the term 'protourbanisation' - even if we have used it in the past which implies a programmed and inevitable progress towards urbanisation, whereas in fact the processes take multiple and varied forms.

Traits common to both works are first the generous presentation of both the structures and the assemblages recovered; readers could have sometimes wished for greater coordination between the two publications, for example by producing maps at the same scale for the sectors under study (e.g. fig. 12.1 in the first work, fig. 1 in the second). This documentation represents an essential dataset now accessible to all and used to interpret the phenomenon of early urbanisation - let us adopt the term used by the authors of the first publication - in the arc north of the Alps and, for the authors of the second work, characterising an embryonic (Celtic) state organisation.

* Musée cantonal d'archéologie et d'histoire, Palais de Rumine, CH 1005 Lausanne, Switzerland

(Email: gilbert.kaenel@unil.ch)

(Translated from the French by Reviews editor)

ANTIQUITY 84 (2010): 568-570

http://antiquity.ac.uk/ant/84/ant840568.htm 
The abundance and quality of the records and analyses in both publications must be highlighted. These include analyses of soil micromorphology, animal bones, plant and fruit remains, charcoal etc. (not detailed here), as well as the pottery - both local and imported from the Mediterranean world the instrumentum and the remains of craft activities amongst other studies. In part the same specialists (e.g. the pottery experts) were commissioned for both works, thus ensuring a certain coherence between the sectors under scrutiny.

It goes without saying that the size of interventions in an urban milieu - the theme of a colloquium held in 2008 in Bourges - is a severely limiting factor (see a number of articles in Buchsenschutz et al. 2009). Since building outlines or a coherent plan of how space was organised cannot be reconstructed, or confirmation that a bank and ditch associated with occupation on the western side of the promontory over the river Yèvre could not be obtained, inferences must necessarily remain summary.

The 'princely complex', to use the terminology of Augier, Buchsenschutz and Ralston, centres on the end of the Hallstatt period, or Hallstatt D2 and particularly D3, i.e. the second half of the sixth and the beginning of the fifth century BC. We shall not dwell here on later testimonies of the La Tène B and C period (i.e. before Caesar's Avaricum, whose archaeological footprint, despite growing evidence from excavation, is still quite slight; see Krausz \& Ralston in Buchsenschutz et al. 2009). These episodes of occupation nevertheless underline a fundamental trend, that is the permanence of certain agglomerations, or at least certain quarters, from the late Hallstatt onwards but exhibiting varied degrees of intensity over the passage of time.

The quantitative approach to the assemblages pursued by Milcent and his collaborators allows us to gauge the different sectors in terms of 'wealth', for example by tracking variations in the percentage of fine wheel-turned pottery from the late Hallstatt onwards. This approach should contribute to refining our understanding of sites grouped together in the 'princely seat' scheme which has, as the author points out, too often categorised them under the same reductionist umbrella, a legacy of the modelling that has taken place over the last forty or so years.

The identification of 'suburbs' (for want of a better word) around the agglomerations is without doubt one of the most innovative aspects of the research recently carried out. It allows us to apprehend the urban phenomenon in a way which differs markedly from the interpretations advanced only a decade ago; in other words to go as far as regarding the Heuneburg or Bourges as veritable towns of several dozen or even hundreds of hectares! Their legal status and that of their inhabitants, or the relationships between town and country will, however, remain unknown in the absence of written documents.

At Bourges the site of Saint-Martin-des-Champs produced evidence of varied and flourishing crafts, including working of copper alloys, iron, lignite, bone, horn and textiles, together with indications of exchange and even long-distance trade, the latter a subject particularly favoured in the latter part of the twentieth century. The storage pits, food refuse and remnants of domestic activity imply occupation in situ, even though no house plans - of houses probably built on light foundations - survive. In comparison to other sites the relatively high percentage $(1 \%)$ of fine pottery made on a slow wheel, of amphorae and of Attic red figure ware shows that such products were not the exclusive preserve of the elite; nor was, for that matter, the consumption of game.

The site of Port-Sec, excavated in 2007 on the northern bank of the river Yèvre some $3 \mathrm{~km}$ northeast of the city of Bourges (see Filippini \& Pescher 2009), where single and double kettle fibulae (fibules à timbale) were manufactured during Hallstatt D3 and La Tène A1 times, provides a splendid example of the role craftsmen played in the organisation of such agglomerations and their surroundings, quite apart from enlarging the periphery of Bourges by several more dozen hectares. But the relationship between these craftsmen and the ruling aristocracy, presumed to be established in the centre, remains to be investigated. In this context, let us also recall the exceptional presence on the promontory of wall plaster with polychrome designs, as has also been uncovered recently at the Mont Lassois.

On the chronological front, the La Tène A period appears not to be represented in the 'town centre' or could not be identified on the basis of the essentially ceramic assemblages. The sites of Saint-Martin-des Champs and of the Etablissements militaires have, on the other hand, produced some 25 fibulae, which places the floruit of this sector in an advanced phase of La Tène A1, i.e. a relatively brief period in the third 
quarter of the fifth century BC; these dates are entirely compatible with the dating provided by the imported amphorae and Attic fine ware. If we are happy to follow Milcent's evaluation of the next phase (La Tène A2) as playing a determining role and marking a 'new historic era', we are not prepared, in terms of chronology and terminology, to see La Tène A1 as corresponding to 'the ultimate phase of the first Iron Age in central Gaul' (p.221); we consider it wiser to dissociate socio-economic or historical ruptures from the terms used in relative chronological terminology. The authors of the first work consider the evidence from Bourges as permitting to extend westwards the western Hallstatt sphere of influence, which would reach from the Berry to BadenWürttemberg; Milcent, in the second volume, defines and circumscribes a 'western north-Alpine province' within the Hallstatt domain. This latter province, identified on the basis of distribution maps, should be subjected to further scrutiny to test the validity of such a concept, in particular with regard to the 'middle Atlantic domain' or with the culture zones in south-western and southern France. In his concluding chapter Milcent paints a vast panorama of the period in its European context, rich in spatial, chronological and historical (in the wider meaning of the term) insights, which goes as far as integrating ancient written sources referring to the Bituriges, Avaricum and Celtic migrations.

In conclusion, these two volumes, here only barely sketched out, must be on the shelves of every protohistorian in Europe and in any library with claims to European archaeology.

\section{References}

Buchsenschutz, O. et al. (ed.) 2009. L'âge du Fer dans la boucle de la Loire: les Gaulois sont dans la ville (Actes du XXXII ${ }^{e}$ colloque de l'Association Française pour l'Etude de l'Age du Fer tenu à Bourges, 1-4 mai 2008) ( $35^{e}$ supplément à la Revue Archéologique du Centre de la France) including a review of the Oppidum of Avaricum by S. Krausz \& I. Ralston.

Filippini, A. \& B. Pescher. 2009. Découverte d'une zone de production de fibules à timbales à Bourges 'Port-Sec Sud' (Dép. Cher). Archaeologisches Korrespondenzblatt 39/1: 77-93. 